\title{
The Future and challenge of Pragmatics in English Language Teaching
}

\author{
Mazulfah \\ IAIN Salatiga \\ mmazulfah@gmail.com
}

Submission
Track:
Received:
23-10-2019
Available online:
30-10-2019
Corresponding
Author:
Mazulfah
mmazulfah@ gmail.com

\begin{abstract}
This paper demonstrates about the future and challenge of pragmatics in English language teaching. In pragmatics, meaning in communication has an important role and it can be categorized into two elements such as verbal and nonverbal. It depends on various contexts, relationship between utterers, and social factors. In English language teaching, pragmatic is very important because the four language skills in language learning such as reading writing, listening and speaking do not occur in isolation in communicative texts or activities. So through forming a good pragmatic competence for the language learner, should be considered. As English has played an indispensable role in global communication, it is important for English language users, both native and non-native, to use clear, comprehensible and educated English that allows smooth communication and avoids misunderstandings in social interactions. Pragmatic competence can facilitate language users to successfully achieve their communicative aims in intercultural communication. Consequently, pragmatic elements have noticeable important in communication between speakers because such elements can hinder inaccuracies and misunderstandings during communication so teachers should teach pragmatic competence in language English classes through different activities and tasks.
\end{abstract}

Keywords: Pragmatics, English language teaching, language competencies.

\section{INTRODUCTION}

Pragmatics is a major study of linguistics that defines the hidden meanings of a writer and speaker towards the conjoining effort of linguistic form. It is stated along with its user. Within 
pragmatics the importance is usually given to a contextual meaning. Crystal (1997) believes that English becomes a truly global language since then it has kept its privileged position among other world languages towards the end of the 20th century. It is estimated that about 1.5 billion people all over the world speak English. According to Kachru's terminology, the Inner Circle countries are the first and majority group language, the Outer Circle countries such as India, Pakistan, Singapore, and Nigeria use English as a second language together with other languages as means of international communication, the Expanding Circle covers an unspecified number of countries which employ English as a foreign language in schools (Kachru \& Nelson, 2001).

As Held et al., (1999) mention "Globalization may be thought of initially as the widening, deepening and speeding up of worldwide interconnectedness in all aspects of contemporary social life" and it is an inevitable process. As Richards (2001) states that English is no longer viewed as the property of the English -speaking world but it is an international commodity sometimes referred to as English an International Language.

One of the important of the pragmatics, in this study is towards a speaker, who wants to convey the contextual meaning towards the hearer according to provided situation. According to the Crystal (1987:62-5); Pragmatics deals with the factors that manages the language for what we want to choose within the pool of language that could satisfy whenever it is used within a social interaction and its effects on others. Therefore, the factors of pragmatics that effect on our selection of grammatical construction are as sound pat-tern, and the meaning which we are producing by presenting the vocabularies through the intended procedure as a way to communicate (Crystal, 1987:62-5). Therefore, the study of pragmatics is tending to relate it with the meaning of words that people used within their social situations and choice of the words in a context.

According to the Robin; the field of pragmatics is understood as meaning concerned phenomenon that involves around the different factors of speech situation, (1964:23). Leech (1983:13-4), pointed that the pragmatics is a study of meaning and the way to relate that speech with any pro-vided situations, along with an aspect to make a speech in a situation and further it paves a path to determine a core principle that whether it deals with semantic or the pragmatic phenomenon. The more important aspects of pragmatics have indicated that it is the study of 
meaning that is related towards speech making situation. Within pragmatics, the five vital aspects that are mainly focused have been mentioned below:

a Addressees or addressers (hearer and speaker)

b An utterance in context, Leech agreed to say the involvement of relevant utterance in social and physical setting, however, he did emphasizes more on the back-ground knowledge that is related to the context.

c Leech defines the goals of an utterance as well as the meaning of intention towards uttering it.

d The utterance is a form of activity or an act, within pragmatics, the verbal utterance can also be performed like acts to parch needs of a particular situation.

e The utterance that is in a form of enclosed verbal acts does tends to identify for sentence or token tagging that in their real sense are not the sentences, but similarly can be the piece of language that classify as short and long single sentence.

Pragmatics deals with meaning and it involves the fundamental approach to view meaning and its relationship with reality. As it is for the related theories of meaning that view the language itself as systematic to designate many specific things and its symbols. The truth about semantics, which focuses on the meaning of the sentence and its purpose, is to analyze different meaning forms to formal way and it also deals with the surface meaning. However it lacks the contextual definition. In simple terms, the field of semantics deals with the overall structure of sentences and it determines the lexical condition of the content that formulates information of meaning from the other sources to supply it (Chapman 2000). A Language can even deal with many other instruments, the instrument that is of thought as well as the instrument of social 
action (Capone, 2005). Therefore, within the scope of pragmatics, the major terms that can be described are as follows:

The Utterance is described as the physical and clear unit of meaning that gives information in the contribution through;

1) Words that are used,

2) Structure of the sentence,

3) Setting of the conversation within location where it is used,

4) Senses of the start in a particular context,

5) To use the gesture in order to covey the meaning.

One of the most important things that are from these sources is taken as context utterance and it is provided with background knowledge to convey a message of information towards the other parts of conversation, like of any written text.

\section{Language competencies}

Language competencies can be classified into sub competencies in the following:

Grammatical competence: Bach man (1990) discusses that grammatical competence consists of the individual's knowledge of vocabulary, morphology, syntax, and phonology.

a) Communicative competence: Canale \& Swain (1980) propose an influential model of communicative competence that includes sociolinguistic competence. Niezgoda \& Rover (2001) summarize the sun competencies under this model as follows: Grammatical competence: The knowledge of linguistic code features such as morphology, syntax, semantics, phonology; b) Sociolinguistic competence: The knowledge of contextually appropriate language use;

c) Discourse competence: The knowledge of achieving coherence and cohesion in spoken or written communication;

d) Strategic competence: The knowledge of how to use communication strategies to handle breakdowns in communication and make communication effective.

Bach man's (1990) model of communicative competence also provides an inclusive description of the knowledge require $d$ to use language. In addition to the knowledge of grammatical rules, communicative competence consists of the knowledge of how language is utilized to achieve particular communicative goals. He categorizes language competence into organizational competence and pragmatic competence. Organizational competence relates to a speakers' control of the formal aspects of language and is further subdivided into grammatical 
competence (vocabulary, syntax, morphology, phonology), and textual competence (cohesion/coherence, rhetorical organization). As noted by Niezgoda \& Rover (2011), Pragmatic competence is classified into sociolinguistic and illocutionary competence.

\section{Pragmatics competence}

Taguchi (2003) mentions that pragmatic knowledge "deals with language use in relation to language users and language use settings." Leech (1983) and Thomas (1983) suggest that pragmatics is classified into two components: pragma linguistics and socio pragmatics. Pragma linguistics deals with pragmatic strategies such as the use of semantic formulae, routines, and linguistic forms that can serve the purpose of making the communicative act more direct or indirect, softer or more intensified. Socio pragmatics relates to social behavior, and the way speakers in a certain community interpret and accomplish a communicative act. As indicated by Leech (1983), pragma linguistics refers to the linguistic/grammatical aspects of a language, while socio pragmatics is driven more towards the socio -cultural end of pragmatics.

As mentioned by Thomas (1995), Pragmatics competence means the ability to use language in socially appropriate ways and to interpret both imp licit and explicit meaning according to context. Since the mid-1970s, the general purpose of language teaching and assessment concentrates on developing learners' communicative competence, knowledge of the pragmatics and linguistics aspects of language use to enable students to become proficient in the target language.

Bach man (1990) supports this approach and describes language ability broadly as "the ability to use language communicatively." He proposes two models in his model which includes two elements: language knowledge and strategic competence. Language knowledge consists of “organizational knowledge" and "pragmatic knowledge." The pragmatic knowledge he refers to considers the appropriateness of a particular communicative goal (what he calls "functional knowledge") and the appropriateness of the language use setting ("sociolinguistic knowledge"). " Rose and Kasper (2001) develop the concept of communicative ability and summarize the study of pragmatics as "the study of communicative action in its socio-cultural context." Communicative action happen not only when one engages in different types of discourse encountered in social situations (which vary in length and complexity depending on the degree of familiarity between interlocutors, differences in social status, and degree of imposition), but 
also when speech acts (such as requests, refusals, apologies, compliments, and suggestions) are employed.

According to Bach man and Palmer (1996), pragmatic knowledge involves the relationship between utterances, language users, and settings support the views of well-known researchers in the field that came before them. Crystal (1985) defines pragmatics as "the study of language from the point of view of users, especially of the choices they make, the constraints they encounter in using social interaction and the effects their use of language has on other participants in the act of communication.

\section{Teaching ability of pragmatics in ESL classes}

According to several ILP studies on how to teach pragmatics which teachers are interested in. on the basis of both empirical and theoretical studies, Awareness -raising is one of an effective approach to the teaching of pragmatics. The purpose of this approach is to develop learners' pragmatic awareness through classroom application of available descriptive frameworks and research results. It does not attempt to teach specific means of, say, performing a given speech act, but rather attempts to sensitize learners to context-based variation in language use and the variables that help determine that variation (Rose, 1994). Drawing from research that focuses on the significance of noticing in language acquisition and L1

Pragmatics development, Schmidt (1993) believes awareness of pragmatic input is considerable for the acquisition of pragmatic competence and in the development of L2 pragmatics. "Consciously noticing to the relevant features of input and attempting to analyze their significance in terms of deeper generalization are both highly facilitative." Hence, tasks that focus the learner's attention on pragmatic forms, functions, and co -occurring features of social context are helpful in developing adult language learners' ILP. Empirical studies in ILP and contrastive pragmatics also indicate that awareness -raising facilitates students in using the pragmatic knowledge they already possess.

Kasper (1997) discovers that L1 and L2 speakers have access to identical lists of semantic formulae and other pragmatic resources, but language learners underuse universal or L1 pragmatic knowledge. Therefore, awareness -raising activities are helpful in making language learners aware of their existing pragmatic competence and encouraging them to utilize the pragmatic resources they already possess. One of the main shortcomings of teaching pragmatics for teachers is that it is so extremely context dependent. No "magic line" will be appropriate for 
all contexts, and it is equally unrealistic to attempt to cover all contexts that students could possibly encounter. By being taught to be aware of pragmatics in various contexts, learners can develop the ability to understand pragmatic patterns in new and previous contexts.

\section{The importance of Pragmatics in ELT}

In English language teaching, pragmatic is very important because the four language skills in language learning such as reading writing, listening and speaking do not occur in isolation in communicative texts or activities. So through forming a good pragmatic competence for the language learner, the following should be considered.

1. The aims of a language course should be designed to meet the needs of the language learner to help them improve their communicative competence. Since the primary goal of learning a second language is to provide fluency and accuracy in written and spoken modes of ommunication, first, the language teacher and the learner should notice to design communicative activities which help to develop the Communicative competence. Stern (1983) summarizes 'competence' in language teaching as:

The intuitive mastery of the forms of language, The intuitive mastery of the linguistic, cognitive, affective and sociocultural meanings, expressed by the language forms, The capacity to use the language with maximum attention to communication and minimum attention to form, The creativity of language use. Obviously, the term competence seeks to develop linguistic and sociolinguistic skills, in order to achieve complete and a c-curate communication for both teachers and learners.

2. Several activities are helpful for the development of pragmatic competence. Furthermore, they should raise the learners' awareness of the importance of such competence in the process of acquiring the target language. As Mey (1993) indicates, "Linguistic behavior is social behavior. People talk because they want to socialize, in the widest possible sense of the world: either for fun, or to express themselves to other humans, or for some 'serious' purposes, such as building a house, closing a deal, solving a problem and so on.

3. The language teacher should design the course material to engage learners in the pragmatic, coherent and functional uses of language for communicative purposes. As claimed by Erton (1997), "The functional study of language means, studying how language is used. For example, 
attempting to discover what the specific aims that language serves for us and how the members of a language community develop and react to these goals through speaking, reading, writing and listening." The pragmatic competence of the learner must be well developed; consequently he or she will be able to conduct communication with accuracy. The development of coherence and the ability to react in different situations demonstrate a good level of functional competence. The grammar of the target language should not be taught in isolation with its use. The learned should be able to put his or her knowledge of language into practice.

\section{CONCLUSION}

In English language teaching, the development of Pragmatics theories and its disciplinary integration of both are very important at present and the future decades since the four language skills in language learning such as reading writing, listening and speaking do not occur in isolation in communicative texts or activities. Through various teaching and learning activities, the development pragmatic competence can be demonstrated and teachers should accept that pragmatic competence is one of the primitive teaching goals. By applying pragmatic competence in English teaching in class, learners can realize various levels of grammars and 
functions well in an accurate, fluent, and coherent way and teachers should teach pragmatic competence in language English classes through different activities and tasks.

\section{REFERENCES}

Bach man, L., \& Palmer, A. (1996). Language testing in practice: Designing and developing useful language tests. Oxford: Oxford University Press.

Canale, M., \& Swain, M. (1980). Theoretical aspects of communicat ive approaches to second language teaching and testing. Applied Linguistics, 1, 1-47.

Capone, A. (2005). Pragmemes (a study with reference to En-glish and Italian). Journal of Pragmatics,37,1355-1371

Crystal, D. (1985). A dictionary of linguistics and phonetics (2nd ed.). Oxford: Blackwell.

Crystal, D. (1997). English as a global language. Cambridge: Cambridge University Press.

Erton, I. (2007). Applied Pragmatics and Competence Relations in Language Learning and Teaching, Journal of Lan-guage and Linguistic Studies , Vol.3, No.1, April 2007

Held, D., McGrew, A., Goldblatt, D., \& Perraton, J. (1999). Global transformations: Politics, economics and culture. Cambridge: Polity Press.

Kachru, B.B., \& Nelson, C.L. (2001). World Englishes. In A. Burns, \& C. Coffin (Eds.), An alyzing English in a g lobal context (pp. 9-25). London and New York: Routledge.

kasper, G. (1997). Can pragmatic competence be taught? NFLRC NetWork (6) Honolulu : University of Hawaii, Sec-

Leech, G. (1983). Principles of pragmatics. London: Longman.

Mey, L. J. (1993). Pragmatics: An Introduction. Oxford: Blackwell Publishers.

Niezgoda, K., \& Röver, C. (2001). Prag mat ic and grammat ical awareness: A function of the learning environment. In K. R. Rose \& K. Kasper (Eds.), Pragmatics in Language Teaching (pp.1-12). Cambridge: Cambridge University Press.

Richards, J.C. (2001). Communicative Language Teaching Today. New York: Cambridge University Press.

Roever, C. (2010). Researching pragmatics. In B. Paltridege \& A. Phakit i (Eds.), Continuum Comparison to Research Methods in Applied Linguistics (pp. 240-255). London, New York: Continuum International Publishing Group. 
Rose, K. R. (1994). Pragmatic Consciousnes s-Raising in an EFL Context.

Rose, K. R., \& Kasper, K. (Eds.). (2001). Pragmatics in language teaching . Cambridge: Cambridge University Press.

Thomas, J. (1995). Meaning in interaction: An introduction to pragmatics. London: Longman. Wardhaugh, R. (1987). Languages in competition. Dominance, diversity, decline. Oxford: Ba sil Blackwell.

Yule, G. (1996). Pragmatics. Oxford: Oxford University Press. 